\title{
Potensi Rumput Laut di Perairan Seram Timur, Kabupaten Seram Bagian Timur, Maluku
}

\author{
Marsya J. Rugebregt ${ }^{1,2 *}$, Ferdinand Pattipeilohy ${ }^{1}$, Caleb Matuanakotta ${ }^{1}$, Ahmad Ainarwowan ${ }^{1}$, \\ Malik Sudin Abdul ${ }^{1}$, Ferdimon Kainama ${ }^{1}$
}

1Pusat Penelitian Laut Dalam - LIPI

2Sekolah Ilmu Lingkungan, Universitas Indonesia

\begin{abstract}
ABSTRAK
Makroalgae termasuk bagian dari flora yang terdiri atas banyak jenis dan memiliki peranan penting pada lingkungan laut salah satunya adalah Perairan Pulau Keffing di Kecamatan Seram bagian Timur, Kabupaten Seram Bagian Timur. Penelitian dilaksanakan pada November 2017. Metode yang digunakan pada penelitian ini adalah metode eksplorasi dengan pengambilan sampel secara line transek kuadrat. Lokasi pengambilan sampel dibedakan menjadi tiga stasiun. Jumlah jenis algae yang dijumpai dalam penelitian ini sebanyak 16 jenis yang terdiri atas 9 jenis dari kelas algae Chlorophyta, satu jenis dari kelas Phaeophyta dan enam jenis dari kelas Rhodophyta. Jenis-jenis yang ditemukan memiliki potensi ekonomi, baik kepada lingkungan periaran maupun kepada manusia, namun pemanfaatannya belum dioptimalkan oleh masyarakat karena sebagian hanya dimanfaatkan untuk makanan. Dari hasil pengukuran parameter lingkungan menunjukan masih sesuai bagi pertumbuhan rumput laut. Perairan pulau Keffing dan sekitarnya memiliki kemungkinan untuk dikembangkannya kegiatan usaha budidaya rumput laut serta pengembangan pengolahan potensinya.
\end{abstract}

Kata kunci: Makroalgae, Pulau Keffing, Chorophyta, Phaeophyta, Rhodophyta

\begin{abstract}
Macroalgae is part of the flora consists of many types and has an important role in the marine environment, one of which is the waters of Keffing Island in the East Seram District, East Seram District. The research was carried out in November 2017. The method used in this study is an exploratory method by taking a sample using a quadratic transect line. The sampling locations were divided into three stations. The number of algae species found in this study was 16 species consisting of 9 species from the Chlorophyta class, one from the Phaeophyta class, and six species from the Rhodophyta class. The species found have economic potential, both for the aquatic environment and for humans, but their utilization has not been optimized by the community because some of them are only used for food. The results of the measurement of environmental parameters show that it is still suitable for seaweed growth. The waters of Keffing Island and its surroundings have the possibility for the development of seaweed cultivation activities and the development of processing potential.
\end{abstract}

Keywords: Macroalgae, Keffing Island, Chorophyta, Phaeophyta, Rhodophyta

Citation: Rugebregt, M.J., Pattipeilohy, F., Matuanakott, C., Ainarwowan, A., Abdul, M.S. dan Kainama, F. (2021). Potensi Rumput Laut Perairan Pulau Keffing, Seram Bagian Timur, Maluku. Jurnal Ilmu Lingkungan, 19(3), 497-510, doi:10.14710/jil.19.3.497-510

\section{Pendahuluan}

Indonesia memiliki Kawasan pesisir dan lautyang mempunyai peranan penting berupa potensi sumberdaya alam dan jasa-jasa lingkungan yang disebut sumberdaya pesisir. Indonesia mempunyai perairan laut yang lebih luas dari daratan, oleh karena itu Indonesia disebut juga negara maritime. Laut Indonesia terkenal kaya dengan keanekragaman biota laut, baik tumbuhan maupun hewan yang memiliki nilai potensial dan memiliki peranan penting secara ekologi dan ekonomi. Ekosistem pantai daerah tropis pada daerah pasang surut (intertidal) mempunyai potensi sumberdaya dan keanekaragaman hayati yang besar (Dahuri et al., 1996), karena daerah pantai dan pesisir adalah daerah yang relatif subur dengan limpahan zat-zat hara yang diperoleh dari daratan dan dari dasar laut.

Pada wilayah terjadinya pasang surut akan ditemukan ekosistem produktif diantaranya mangrove, lamun, dan alga, yang memiliki nilai ekologis yang penting sebagai habitat, tempat mencari makan, memijah, dan berlindung dari beberapa biota laut. Namun pada daerah ini juga paling banyak dimanfaatkan oleh manusia. Adanya penggalian pasir, batuan, karang, dan kegiatan rekreasi adalah kegiatan

\footnotetext{
*Penulis korespondensi: marsya.rugebregt@gmail.com
} 
manusia yang dilakukan manusia di daerah pasang surut. Makroalgae (rumput laut) yang dikenal juga sebagai algae merupakan tumbuhan thallus (Thallophyta) dimana organ-organ berupa akar, batang dan daunnya belum terdiferensiasi dengan jelas (belum sejati).

Jenis makroalgae di Indonesia sebagian besar bernilai ekonomis tinggi sebagai makanan dan obatobatan. Indonesia memiliki kurang lebih 628 jenis makro algae dari 8000 jenis makro algae yang ditemukan di seluruh dunia (Luning, 1990). Makroalgae adalah organisme produsen memberikan bagi biota akuatik terutama organisme-organisme herbivora di laut (Atmadja, 2009; Almeida et al., 2016). Dari segi ekologi, makroalgae berfungsi sebagai penyedia karbonat dan sebagai pengokoh substrat dasar yang berfungsi sebagai penyeimbang untuk keberlanjutan terumbu karang. Manfaat lain dari makroalgae adalah untuk menunjang kebutuhan hidup manusia sebagai bahan pangan dan industri (Subaryanti et al., 2013).

Pulau Keffingadalah salah satu pulau yang memiliki keanekaragaman jenis makralgae yang tersebar pada berbagai habitat dan belum teridentifikasi jenis dan sebarannya, baik pada ekosistem lamun maupun pada terumbu karang. Belum adanya kajian khusus mengenai makroalgae di perairan Pulau Keffing yang menjadi alasan penelitian ini. Dengan demikian maka penelitian ini perlu dilakukan untuk mengetahui komposisi jenis dan sebaran makroalgae pada ekosistem lamun dan terumbu karang di Pulau Keffing. Dari hasil penelitian ini diharapkan dapat memberikan rekomendasi pengelolaan rumput laut yang berkelanjutan di Pulau Keffing dan Kabupaten Seram Bagian Timur (SBT) Propinsi Maluku.

\section{Metode Penelitian}

Penelitian dilaksanakan pada akhir bulan November 2017. Lokasi penelitian adalah Perairan Pulau Keffing Kecamatan Seram Timur, Kabupaten Seram Bagian Timur, Maluku (gambar 1). Alat yang dipergunakan dalam penelitian adalah meteran roll, tali plastik/nylon, kuadran dari pipa paralon $(50 \times 50 \mathrm{~cm})$, kantong plastik, alat tulis, kamera digital. Bahan yang digunakan dalam penelitian adalah larutan alkohol $70 \%$.

Metode yang digunakan pada penelitian ini adalah metode eksplorasi dengan pengambilan sampel secara line transek kuadrat $(50 \times 50 \mathrm{~cm})$. Lokasi pengambilan sampel dibedakan menjadi tiga stasiun. Penentuan ketiga stasiun tersebut berdasarkan perbedaan tipe letak, yaitu stasiun I pada bagian selatan pulau Keffing, stasiun II pada bagian utara Pulau Keffing dan stasiun III pada bagian barat Pulau Keffing.

Pengumpulan data dengan metode transek kuadrat yang dibuat tegak lurus garis pantai ke arah tubir (slope) dengan selang 100 meter. Pada setiap interval 10 meter dari garis pantai dilakukan sampling biomassa rumput laut pada bingkai (plot) berbentuk empat persegi (bahan paralon) dengan ukuran 1 x 1 meter (artinya pada setiap interval 10 meter diletakkan bingkai tersebut, kemudian dilakukan pengambilan sampel makro alga yang berada dalam bingkai empat persegi), dan sampel tersebut dimasukan dalam kantung plastik dan diberi label (Papalia dan Arfah, 2013). Selanjutnya sampel makro alga diseleksi dan dipisahkan menurut jenis dan marga serta ditimbang berat basahnya.

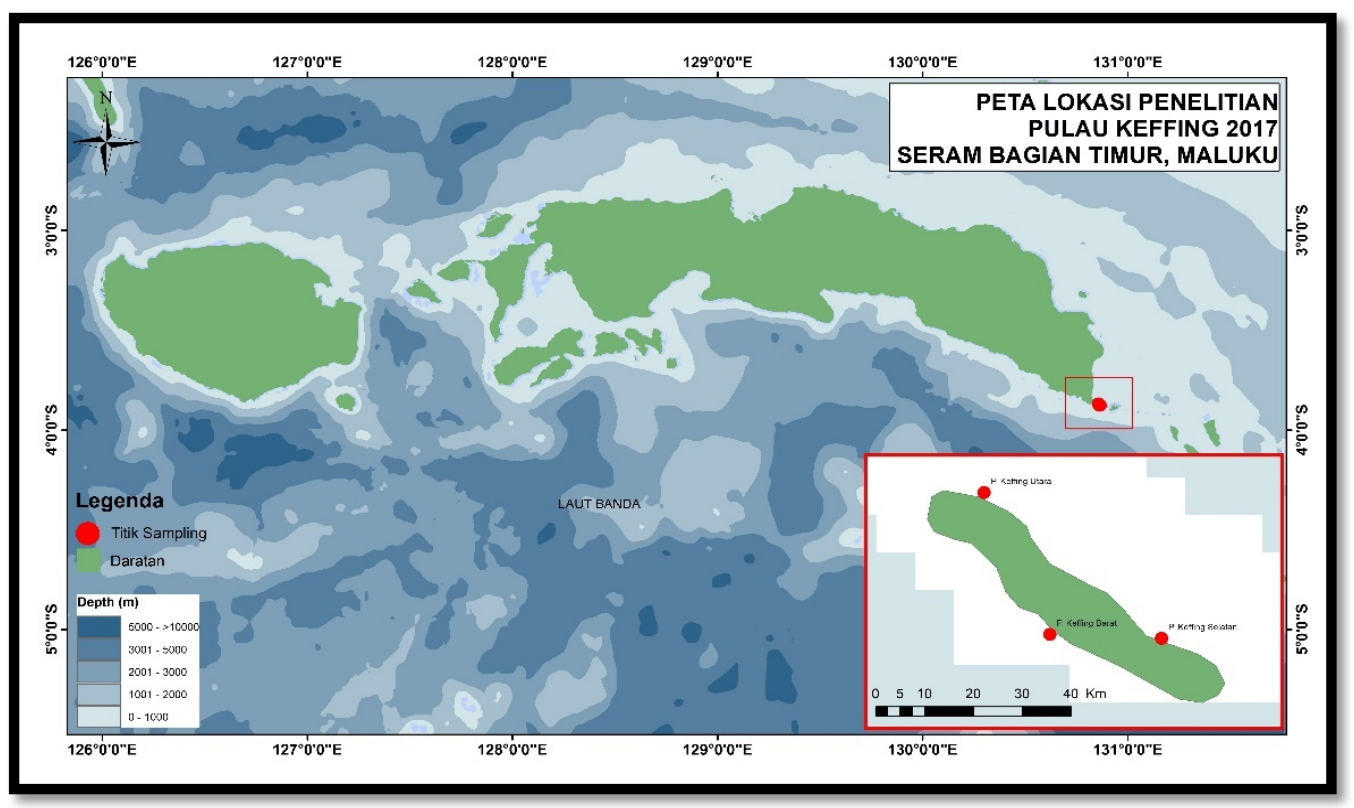

Gambar 1. Lokasi Penelitian Pulau Keffing, SBT, Maluku 
Setelah dilakukan pengambilan sampel, dilanjutkan dengan proses identifikasi. Sampel makroalgae yang diambil kemudian diidentifikasi memperhatikan ciri atau karakter khas yang ada pada setiap sampel (Bhavanath et al., 2009; Cordero,1980). Sampel makroalgae dimasukkan ke dalam plastik sampel dan diawetkan dengan direndam dalam larutan Alkohol $70 \%$.

Data makro alga dianalisa berdasarkan indeksindeks ekologi yaitu indeks kepadatan (e), menurut Odum (1993), Frekuensi kehadiran (Takandare, 2005 dalam Papalia dan Arfah, 2013) dan Indeks dominansi (Odum, 1993).

Kepadatan Total (gram $/ \mathrm{m}^{2}$ ) dalah jumlah individu per satuan luas area (Brower and Zar, dalam Papalia dan Arfah, 2013) dihitung sebagai berikut:

$$
\mathrm{Di}=\mathrm{ni} / \mathrm{A} \text {. }
$$

Dimana: $\mathrm{Di}=$ kepadatan spesies untuk spesies ke-i, ni=jumlah total individu spesies ke-i, dan A=luas total daerah yang disampling.

Frekuensi Kehadiran (ind) menunjukan banyaknya petak pengamatan dimana suatu spesies ditemukan dalam luasan tertentu (Takandare, 2005) dihitung sebagai berikut:

$$
\mathrm{Fi}=\mathrm{Ji} / \mathrm{K}
$$

Dimana: $F i=f r e k u e n s i$ relatif untuk spesies ke-i, Ji=jumlah plot yang terdapat spesies ke-i, dan $\mathrm{K}=$ jumlah total plot yang dibuat.

$$
\text { Indeks Dominansi (Indeks Simpson) }
$$
menunjukkan spesies tertentu yang paling banyak terdapat dalam komunitas. Dominansi spesies ditentukan berdasarkan indeks Simpson dengan merujuk pada rumus yang diterapkan oleh Odum, (1975) dalam (Papalia dan Arfah, 2013) dihitung sebagai berikut:

$$
\mathrm{D}=\sum p i^{2}
$$

Dimana: $\mathrm{D}=$ nilai indeks dominan spesies, pi=kelimpahan relatif dari spesies ke-i (ni/N).

Nilai indeks dominansi berkisar antara $0-1$, bilamana $\mathrm{D}=1$ maka dominansi tinggi (ada spesies yang dominan) dan bilamana $0<\mathrm{D}$.

Parameter kualitas air yang diukur adalah suhu, $\mathrm{pH}$, kedalaman air, dan kuat arus air. Suhu, kedalaman air dan kuat arus diukur menggunakan current meter. Pengukuran $\mathrm{pH}$ menggunakan $\mathrm{pH}$ meter.

\section{Hasil dan Pembahasan}

\subsection{Makroalgae di Perairan Pulau Keffing}

Berdasarkan hasil penelitian, makroalgae yang ditemukan di lokasi penelitian sebanyak adalah 16 jenis. Makroalgae tersebut digolongkan dalam 3 divisi yaitu Chlorophyta, Phaeophyta, dan Rhodophyta
(Tabel 1). Untuk divisi Chlorophyta ada 9 jenis makroalgae yaitu Halimeda opuntia, Halimeda macroloba, Halimeda mcroloba decaisne, Halimeda borneensi, Caulerpa racemosa (Forsskal) J. Agardh, Caulerpa lentillifera, Caulerpa sertularioides, Caulerpa racemosa (Forsskal) J. Agardh, Chaetemorpha crassa, dan untuk divisi Phaeophyta berdasarkan hasil penelitian hanya ada 1 jenis makroalgae yaitu Padina australis. Sementara itu, untuk divisi Rhodophyta ada 6 jenis makroalgae yaitu Achanthopra muscoides, Amphiroa fraglisima, Gelidiella acerosa, Gracilaria salicornia, Gracilaria arcuata dan Hypnea cervicornis.

Jenis makroalgae yang banyak dijumpai di lokasi penelitian yaitu jenis dari divisi Chlorophyta. Pada umumnya algae Chlroophyta tumbuh berumpun. Keberadaannya dapat dijumpai di perairan terumbu karang dan goba (Kadi, 2005). Chlorophyta tumbuh atau menempel di substrat dasar perairan seperti karang mati, fragment karang, pasir dan pasir berlumpur. Pertumbuhannya bersifat epifitik atau saprofitik dan kadang kadang berasosiasi dengan tumbuhan lamun (Firdaus, 2019).

Tumbuhan Saprofit adalah tumbuhan yang tumbuh pada makhluk hidup yang telah mati. Tumbuhan saprofit membantu proses pembusukan. Dengan adanya pembusukan maka diperoleh zat-zat yang lebih sederhana. Zat-zat yang sederhana ini sangat bermanfaat untuk menyuburkan tanah dan dimanfaatkan oleh makhluk hidup yang lain. Tumbuhan epifitik hidup dan menempel pada tumbuhan lain, tetapi dapat mencari makanan sendiri (Fifendy, 2017). Karena sifat tersebut diatas maka, hasil penelitian yang dilakukan pada stasiun I (Keffing Bagian Selatan) kesuburan perairan pada lokasi ini ditunjukan dengan ditemukannya berbagai biota dan laut lainnya yang hidup subur dan melimpah di komunitas benthos.

Teripang, bintang laut, kerang, ikan, lamun dan bahkan laor (Policaeta) yang dapat hidup dan ditemukan hampir di setiap bulan, Hal ini sangat berbeda dengan laor yang hidup di daerah lain yang hanya sekali dalam setahun. Dugaan kami, bahwa laor yang dapat hidup setiap bulan adalah akibat kesuburan perairan yang cukup tinggi dengan adanya Algae Halimeda minima (W.R.Taylor) Hillis-Colinvaux tumbuh dengan subur dan lebat diatas fosil-fosilnya sendiri dan berbentuk hamparan yang cukup besar dan ketebalan fosil mencapai 30-50 cm dari permukaan dasar perairan, sehingga keberadaannya sebagai rumah untuk tempat hidup dan sekaligus sumber makanan bagi biota lainnya (Draw, 1995).

Algae jenis Caulerpa hidup menempel dengan subur pada algae Helimeda. Dengan demikian algae Halimeda sp. tumbuh subur dengan sifatnya sebagai tumbuhan saprofit sedangkan untuk algae Caulerpa sp. memiliki sifat epifitik. 
Tabel 1. Hasil Inventarisasi Makroalgae Di Perairan Pulau Keffing Dan Sekitarnya

\begin{tabular}{|c|c|c|c|c|}
\hline \multirow{2}{*}{ No } & \multirow{2}{*}{ Jenis } & \multicolumn{3}{|c|}{ Lokasi } \\
\hline & & Keffing Bag. Selatan & Keffing Bag. Utara & Keffing Bag. Barat \\
\hline $\mathbf{A}$ & Chlorophyta & & & \\
\hline 1 & Halimeda minima (W.R.Taylor) Hillis-Colinvaux & + & + & + \\
\hline 2 & Halimeda macroloba & + & + & + \\
\hline 3 & Halimeda mcroloba decaisne & + & + & + \\
\hline 4 & Halimeda borneensis & + & + & + \\
\hline 5 & Caulerpa racemosa (Forsskal) J. Agardh & + & + & + \\
\hline 6 & Caulerpa lentillifera & + & + & + \\
\hline 7 & Caulerpa sertulariodes & + & + & + \\
\hline 8 & Caulerpa racemosa (Forsskal) J. Agardh & + & + & + \\
\hline 9 & Chaetomorpha crassa & - & + & - \\
\hline B & Phaeophyta & & & \\
\hline 1 & Padina australis & - & + & - \\
\hline C & Rhodophyta & & & \\
\hline 1 & Achanthopora muscoides & - & + & - \\
\hline 2 & Amphiroa fraglisima & - & + & - \\
\hline 3 & Gelidiella acerosa & - & + & - \\
\hline 4 & Gracilaria salicornia & - & + & - \\
\hline 5 & Gracilaria arcuata & - & + & - \\
\hline 6 & Hypnea cervicornis & - & + & - \\
\hline
\end{tabular}

Sumber data diolah dari hasil data lapangan Survei Keffing 2017

Kelompok algae coklat (Phaeophyta) mempunyai bentuk yang beragam namun sebagian besar jenisnya berwarna coklat atau pirang (Irawan dan Lutfi, 2017). Warna tersebut tahan dan tidak berubah walaupun rumput ini mati atau kekeringan. Namun beberapa jenis algae coklat seperti Sargassum, warnanya berubah akan menjadi hijau kebiruan apabila mati kekeringan. Ukuran thalli atau rumpun beberapa jenis algae coklat tumbuh lebih tinggi dari jenis-jenis algae merah dan hijau. Untuk kelompok algae coklat yang berhasil ditemukan dalam penelitian ini adalah jenis Padina australis, sedangkan untuk jenis lainnya seperti Sargassum Sp., Turbinaria Sp. tidak ditemukan karena waktu pelaksanaan penelitian sudah melewati waktu periode tumbuh algae tersebut.

Algae merah (Rhodophyta) adalah kelompok algae mempunyai keanekaragaman dalam bentuk dan variasi warna. Yang menunjukan jenis algae merah adalah terjadinya perubahan warna dari warna aslinya menjadi ungu bila algae tersebut terkena panas matahari secara langsung. Ukuran thalli atau rumpun pada algae merah umunya tidak begitu besar dibandingkan dengan beberapa jenis algae coklat seperti Sargassum. Jenis yang banyak tumbuh dan dijumpai dari kelompok algae ini adalah Garcilaria dan hypnea.

Lokasi P. Keffing bagian Utara memiliki tingkat keanekaragaman yang lebih banyak dari dua lokasi lainnya. Kepadatan makro algae di perairan disebabkan oleh kecepatan arus dan nutrien yang ada di perairan. Kecepatan arus merupakan salah satu parameter yang mempengaruhi kepadatan makro algae di perairan dikarenakan hal tersebut dapat mempengaruhi daya lekat holdfast dan penyebaran spora di perairan (Atmadja, 1996). Ismail (2014) juga menambahkan pada penelitiannya pergerakan ombak besar dan angin yang bertiup kencang menyebabkan makro alga lepas dari substratnya.

Tabel 2. Komposisi Makro algae Di Perairan Pulau Keffing Dan Sekitarnya

\begin{tabular}{|c|c|c|c|c|c|c|}
\hline \multirow[t]{2}{*}{ Marga } & \multicolumn{2}{|c|}{ Keffing Bag. Selatan } & \multicolumn{2}{|c|}{ Keffing Bag. Utara } & \multicolumn{2}{|c|}{ Keffing Bag. Barat } \\
\hline & Jenis & Marga & Jenis & Marga & Jenis & Marga \\
\hline CHLOROPHYCEAE & 8 & 3 & 9 & 4 & 8 & 3 \\
\hline PHAEOPHYCEAE & 0 & 0 & 1 & 1 & 0 & 0 \\
\hline RHODOPHYCEAE & 0 & 0 & 6 & 5 & 0 & 0 \\
\hline JUMLAH JENIS & 8 & & 16 & & 8 & \\
\hline JUMLAH MARGA & & 3 & & 10 & & 3 \\
\hline
\end{tabular}




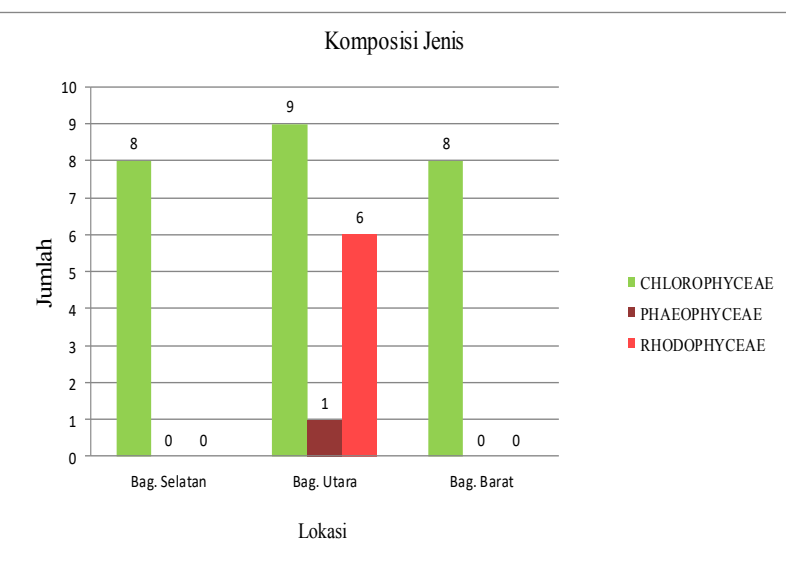

Gambar 2. Grafik Komposisi Jenis makroalgae t di lokasi penelitian

Berdasarkan data pada tabel 2 diatas menunjukan bahwa komposisi makroalga pada masing-masing lokasi penelitian terlihat bahwa di perairan Keffing bagian Utara lebih tinggi dari komposisi makroalga yang berada pada daerah Keffing bagian Selatan dan Utara, data tersebut menunjukan bahwa jumlah jenis yang ditemukan sebanyak 16 jenis dari 10 marga.

Jumlah jenis yang di tampilkan dalam Gambar 2 menunjukan bahwa lokasi perairan Keffing bagian Utara memiliki komposisi jenis yang cukup tinggi pada kelas Cholorophyceae yaitu sebesar 9 jenis dan komposisi jenis yang terendah berasal dari jenis makro algae dari kelas Phaeophyceae yaitu sebanyak 1 jenis yang berhasil ditemukan di lokasi yang sama. Sedangkan untuk Jenis rumput laut dari kelas Rhodophyceae yang berhasil ditemukan hanya terdapat di lokasi periaran Keffing Bagian Utara dengan jumlah jenis sebanyak 6 jenis, sementara pada kedua lokasi lainnya tidak ditemukan.

Komposisi marga dari kelas Rhodophyceae ditemukan cukup tinggi pada peraiaran Keffing Bagian Utara yaitu sebanyak 10 Marga, sedangkan komposisi Marga pada lokasi Keffing bagian Selatan dan Barat hanya memiliki 3 komposisi marga dari kelas
Chlorophyceae, sementara komposisi marga terendah yang berhasil ditemukan adalah kelas Phaeophyceae dari lokasi Keffing Bagian Utara yaitu 1 marga (Gambar 3).

Kadi (2004) menyatakan jenis-jenis makroalga tertentu hidup secara musiman. Jenis-jenis makro alga dari marga Acanthophora, Codium, Gelidiella, Galaxaura, Amphiroa, dan Gracilaria lebih cenderung hidup menempel pada habitat karang mati maupun pecahan karang mati dan berpasir. Pada musim-musim tertentu muncul dan meletakkan thalus pada habitnya, kemudian pada saat-saat tertentu menghilang karena telah dewasa. Hal ini terbukti dengan hasil penelitian yang menunjukan bahwa alga yang di temukan pada lokasi penelitian mempunyai thalus yang sudah dewasa dan berukuran kecil.

Hasil analisis kepadatan makro alga yang diperlihatkan pada Tabel 3 menunjukan bahwa jenis Halimeda minima memiliki kepadatan tertinggi dari 16 jenis yang berhasil di identifikasi yaitu sebesar 3196,7 gr $/ \mathrm{m}^{2}$ pada lokasi Keffing Bagian Selatan sedangkan nilai kepadatan terendah adalah jenis Bornetella oligospora $\left(35,2 \mathrm{gr} / \mathrm{m}^{2}\right)$ pada lokasi Keffing Bagian Utara.

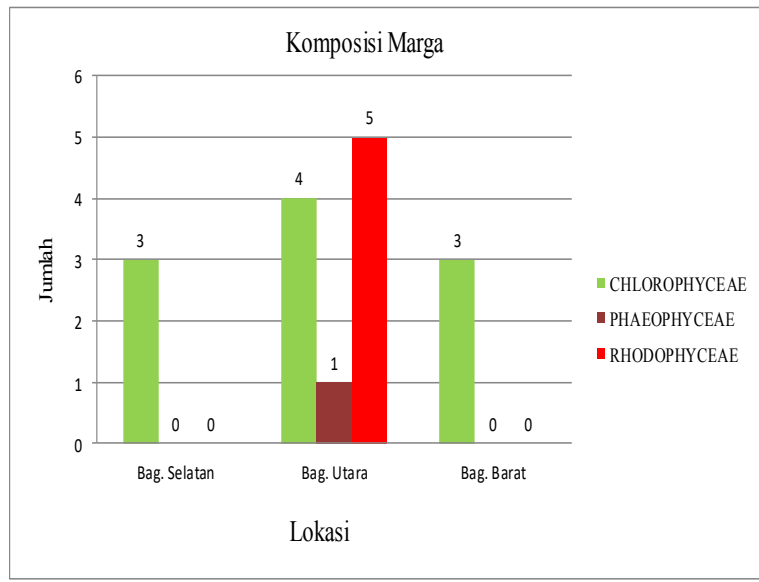

Gambar 3. Grafik Komposisi Marga makroalgae di lokasi penelitian

Tabel 3. Kepadatan makroalgae yang diperoleh dalam penelitian

\begin{tabular}{|c|c|c|c|c|}
\hline \multirow[b]{2}{*}{ No } & \multirow[b]{2}{*}{ Jenis } & \multicolumn{3}{|c|}{ Lokasi } \\
\hline & & $\begin{array}{c}\text { Keffing Bag. Selatan } \\
\text { (gram) }\end{array}$ & $\begin{array}{l}\text { Keffing Bag. Utara } \\
\text { (gram) }\end{array}$ & $\begin{array}{l}\text { Keffing Bag. Barat } \\
\text { (gram) }\end{array}$ \\
\hline 1 & $\underline{\text { Halimeda minima }}$ & 3196,7 & 2092,6 & 570,5 \\
\hline 2 & $\overline{\text { Halimeda macrolo }}$ ba & 758,8 & 502,2 & 325,6 \\
\hline 3 & Halimeda mcroloba decaisne & 435,4 & 332,5 & 269,8 \\
\hline 4 & Halimeda borneensis & 418,3 & 331,9 & 213,7 \\
\hline 5 & Caulerpa racemosa & 409,1 & 410,4 & 162,5 \\
\hline 6 & Caulerpa lentillifera & 379,6 & 277,6 & 181,5 \\
\hline 7 & Caulerpa sertulariodes & 207,9 & 162,6 & 129 \\
\hline 8 & Bornetella oligospora & 71 & 35,2 & 51,7 \\
\hline 9 & Chaetomorpha crassa & 0 & 40,8 & 0 \\
\hline 10 & Padina australis & 0 & 136 & 0 \\
\hline 11 & Achanthopora muscoides & 0 & 95,9 & 0 \\
\hline 12 & Amphiroa fraglisima & 0 & 71,2 & 0 \\
\hline 13 & Gelidiella acerosa & 0 & 77,8 & 0 \\
\hline 14 & Gracilaria salicornia & 0 & 106,1 & 0 \\
\hline 15 & Gracilaria arcuata & 0 & 107,6 & 0 \\
\hline 16 & Hypnea cervicornis & 0 & 71,3 & 0 \\
\hline & Total Jenis & 5876,8 & 4851,7 & 1904,3 \\
\hline
\end{tabular}




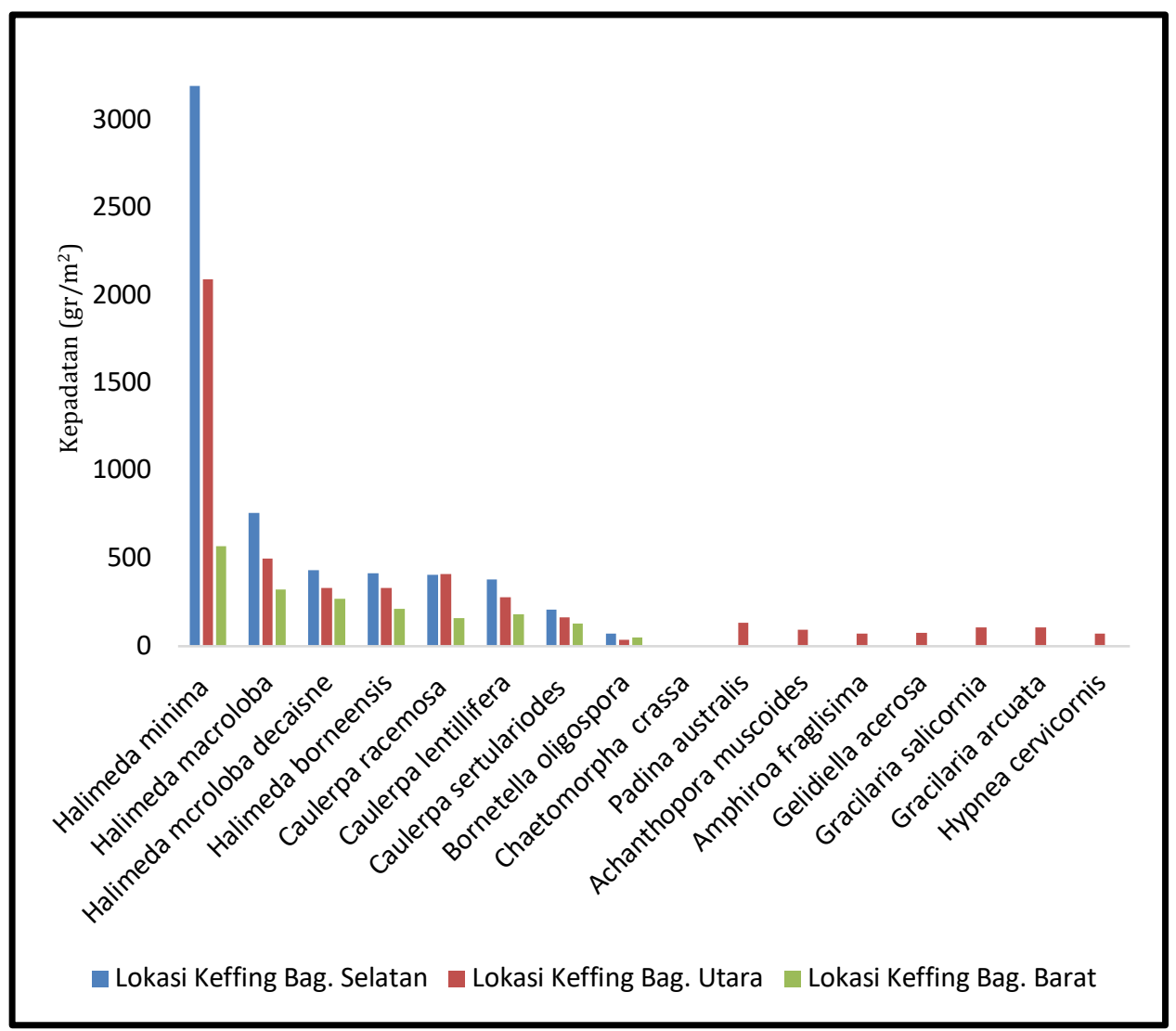

Gambar 4. Grafik Kepadatan makroalgae pada setiap lokasi penelitian

Dari hasil pengukuran tersebut juga menunjukan bahwa lokasi Keffing Bagian Selatan adalah lokasi yang memiliki tingkat kepadatan makro algae cukup tinggi dari 3 lokasi penelitian yang dilakukan yaitu sebesar $5876,8 \mathrm{gr} / \mathrm{m}^{2}$. Sementara dari tabel menunjukan pula bahwa sebaran makro algae yang cukup merata adalah pada lokasi Keffing bagian Utara dimana hasil penelitian menunjukan bahwa jenis yang berhasil di temukan sebanyak 16 jenis dengan nilai kepadatan yaitu sebesar 4851,7 $\mathrm{gr} / \mathrm{m}^{2}$ (Gambar 4).

Berdasarkan tampilan data pada Tabel 4 menunjukan bahwa frekuensi kehadiran makro algae dari 10 marga yang berhasil diidentifikasi pada 3 lokasi penelitan, memperlihatkan bahwa Perairan Keffing bagian Utara memiliki sebaran jenis yang sangat tinggi yaitu terdapat 10 marga sekalipun dalam rata rata persentase tidak terlalu tinggi $(0,08 \%)$ dibandingkan dengan perairan Keffing bagian Selatan dan Barat yang memiliki kehadiran yang sangat tinggi yaitu sebesar 0,35 \% yang sebaran hanya 3 marga dari 10 marga. Sedangkan untuk marga yang frekuensi kehadirannya paling tinggi adalah marga Halimeda seperti yang tampak dalam Gambar 5.

Tabel 4. Frekuensi Kehadiran Makroalgae

\begin{tabular}{clccc}
\hline \multirow{2}{*}{ No } & \multirow{2}{*}{ Marga } & \multicolumn{3}{c}{ Lokasi } \\
\cline { 3 - 5 } & Halimeda & Keffing Bag. Selatan & Keffing Bag. Utara & Keffing Bag. Barat \\
\hline 1 & Caulerpa & 0,50 & 0,25 & 0,50 \\
2 & 0,38 & 0,04 & 0,38 \\
3 & Bornetella & 0,16 & 0,06 & 0,16 \\
4 & Chaetomorpha & 0 & 0,06 & 0 \\
5 & Padina & 0 & 0,06 & 0 \\
6 & Achanthopora & 0 & 0,06 & 0 \\
7 & Amphiroa & 0 & 0,06 & 0 \\
8 & Gelidiella & 0 & 0,06 & 0 \\
9 & Gracilaria & 0 & 0,13 & 0 \\
10 & Hypnea & 0 & 0,06 & 0,35 \\
\hline
\end{tabular}




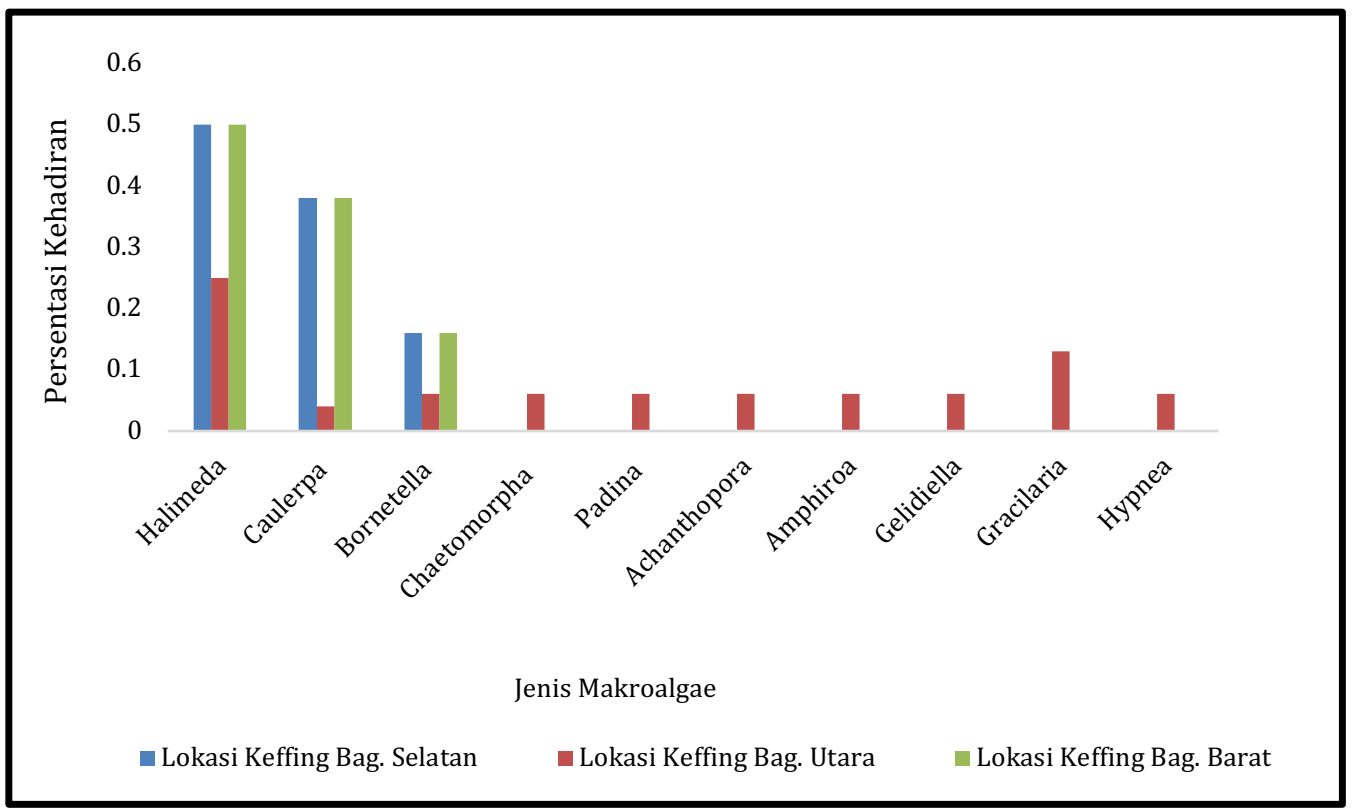

Gambar 5. Grafik Frekuensi Kehadiran makroalgae

Marga makro algae yang kehadirannya di seluruh lokasi penelitian yang berhasil di temukan adalah Halimeda, Caulerpa dan Bornetella sementara marga yang kehadirannya sangat kecil adalah Chaetemorpha, Padina, Achanthopora, Amphiroa, Gelidiella (Tabel 4).

Tabel 5 menunjukan bahwa dominasi marga makro algae cukup tinggi berada pada lokasi perairan Keffing bagian Utara yaitu sebanyak 10 marga dari 3 kelas yang berhasil diperoleh dalam penelitian ini, sekalipun secara persentasenya berada di bawah perairan Keffing bagian Selatan dan Barat yaitu 0,03\%.
Dari hasil analisa data yang dilakukan pada ketiga lokasi penelitian memperlihatkan dari 10 marga yang ditemukan bahwa marga yang memiliki dominasi yang paling tinggi adalah marga Halimeda pada lokasi Keffing bagian Selatan dan Utara yaitu sebesar 0,45\% dan 0,42\% kemudian disusul oleh marga Caulerpa dengan dominasi sebesar 0,16\% dan 0,19\% (Gambar 6). Untuk marga Chaetemorpha, Achanthopora, Amphiroa, Gelidiella, dan Hypnea memiliki dominasi terendah yaitu 0,01 \% di lokasi perairan Keffing bagian Utara.

Tabel 5. Dominasi makroalgae yang diperoleh pada lokasi penelitian

\begin{tabular}{|c|c|c|c|c|}
\hline \multirow[b]{2}{*}{ No } & \multirow[b]{2}{*}{ Marga } & \multicolumn{3}{|c|}{ Lokasi } \\
\hline & & $\begin{array}{c}\text { Keffing Bag. } \\
\text { Selatan } \\
(\%)\end{array}$ & $\begin{array}{c}\text { Keffing Bag. Utara } \\
(\%)\end{array}$ & $\begin{array}{c}\text { Keffing Bag } \\
\text { Barat } \\
(\%)\end{array}$ \\
\hline 1 & Halimeda & 0,45 & 0,16 & 0,42 \\
\hline 2 & Caulerpa & 0,16 & 0,02 & 0,19 \\
\hline 3 & Bornetella & 0,02 & 0,01 & 0,03 \\
\hline 4 & Chaetomorpha & 0 & 0,01 & 0 \\
\hline 5 & Padina & 0 & 0,01 & 0 \\
\hline 6 & Achanthopora & 0 & 0,01 & 0 \\
\hline 7 & Amphiroa & 0 & 0,01 & 0 \\
\hline 8 & Gelidiella & 0 & 0,01 & 0 \\
\hline 9 & Gracilaria & 0 & 0,03 & 0 \\
\hline \multirow[t]{2}{*}{10} & Hypnea & 0 & 0,01 & 0 \\
\hline & Rata rata & 0,21 & 0,03 & 0,21 \\
\hline
\end{tabular}




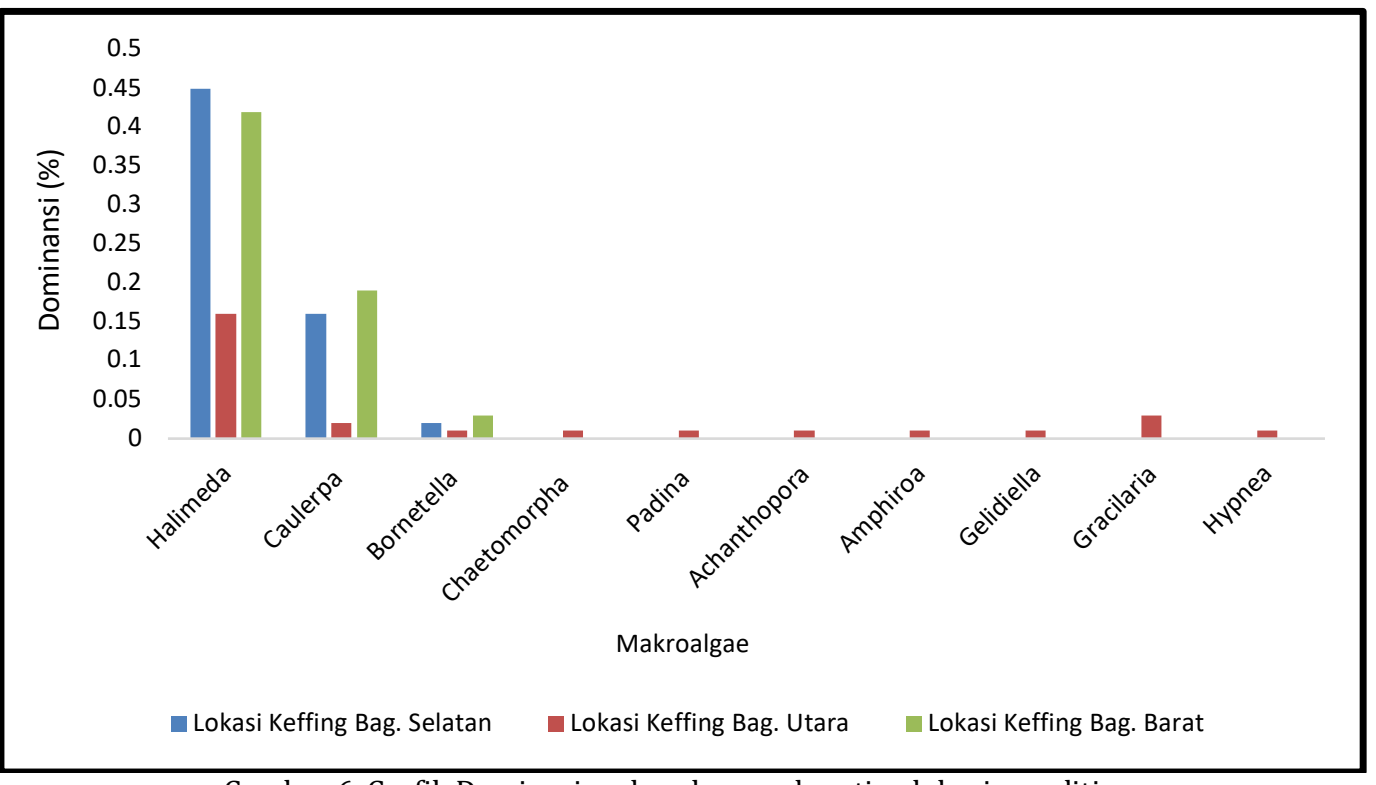

Gambar 6. Grafik Dominasi makroalgae pada setiap lokasi penelitian

\subsection{Potensi Algae}

Perairan pulau Keffing dan sekitarnya memiliki potensi dan peluang untuk dikembangkan dalam kegiatan budidaya rumput laut. Masyarakat sekitar belum menambah peluang usaha budidaya rumput laut serta mengelola hasil potensi kekayaan perairan yang ada secara maksimal. Identitas Jenis dan habitat, sebaran, nilai dan potensi ekonominya dikemukan dalam riset ini untuk mengenal dan memperluas pemanfaatannya. Dari sekitar 629 jenis rumput laut termasuk dalam 189 marga yang tercatat dari perairan Indo-Pasifik termasuk Indonesia, sejumlah 58 jenis diantaranya di manfaatkan (Suparmi dan Sahri, 2009). Di Indonesia, rumput laut sudah sejak lama dikonsumsi secara langsung baik dimakan mentah sebagai lalap atau dijadikan kue oleh masyarakat seperti yang kita jumpai di Maluku, Sulawesi, Papua, Jawa, Bali, NTB, NTT.

Ada beberapa kelompok rumput laut yang telah dikenal dalam dunia perdagangan dan telah dimanfaatkan sebagai bahan baku dalam industri farmasi, kosmetik, bahan campuran berbagai industri, makanan serta beberapa jenis yang berkhasiat sebagai bahan obat atau bahkan diekspor (Tabel 2). Kandungan kimia rumput laut yang bermanfaat antara lain adalah karbohidrat yang berupa polisakharida seperti agar, karaginan dan alginat; mineral; protein; lemak; vitamin; dan yodium. Kawasan perairan pulau Keffing dan sekitarnya memiliki potensi dan peluang untuk dikembangkan dalam kegiatan budidaya rumput laut. Masyarakat sekitar belum mengoptimalkan peluang usaha budidaya rumput laut serta mengelola hasil potensi kekayaan perairan yang ada secara maksimal.

\section{A. Algae Hijau (Chlorophyta)}

Algae hijau dikenal sebagai bahan sayur mayur dengan karakteristik thalli mengandung khlorofil $\alpha, \beta$, $\lambda ; \beta-\gamma$ karoten, santhofil dan thilakoid. Komposisi plastida terdapat pirenoid, dinding sel mengandung sellulose dan mannan. Persediaan makanan didalam thalli berupa kanji (starch), protein, asam amino dan lemak. Kandungan kimia esensial yang paling menonjol adalah vitamin C banyak dijumpai dari marga Caulerpa mencapai 1000 - 32001.U/mg dan rumput laut hijau mengandung koloid berkadar rendah (Dubinsky et al., 1978 dalam Kadi, 2005). Di bidang peternakan rumput laut hijau sebagai bahan industri pakan campuran ternak. Di beberapa negara rumput laut ini digunakan dalam industri makanan yakni sebagai pembungkus makanan dan langsung dapat dimakan. Di restoran Cina disajikan dalam bentuk segar sebagai sayuran dan lalap. Kelompok rumput laut hijau dikenal sebagai "Sea vegetable"sebagai obat anti jamur, anti bakteri dan tekanan darah tinggi (Kadi, 2005). Selain itu khusus untuk Halimeda mempunyai nilai penting secara ekologis di daerah perairan tropis (Bandeira-Pedrosa et al., 2004), dan mempunyai aktivitas anti bakteri (Mtolera \& Semesi, 1996), anti jamur (Dzeha et al., 2003), dan juga kaya akan antioksidan (Yoshie et al., 2002; Linares et al., 2004). 


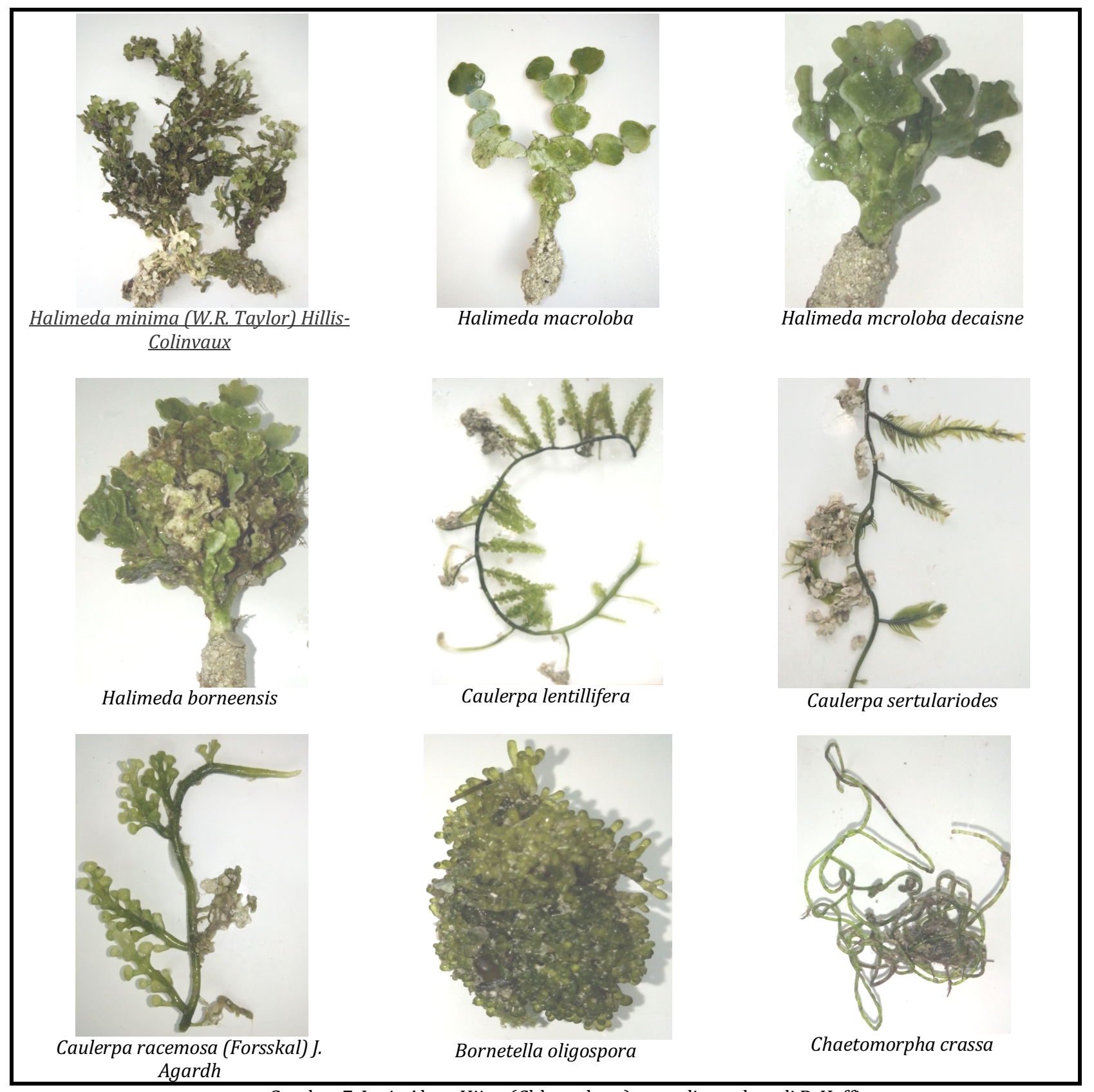

Gambar 7. Jenis Algae Hijau (Chlorophyta) yang ditemukan di P. Keffing

\section{B. Algae Coklat (Phaeophyta)}

Algae ini lebih dikenal sebagai penghasil algin dan iodine. Karakteristik kandungan thalli lebih didominasi oleh pigmen dengan khlorofil a, c, beta karoten, violassantin dan fucosantin. Plastida terdapat pirenoid dan thilakoid. Persediaan makanan dalam thalli berupa laminarin (beta 1-3 ikatan glucan) (Merdekawati dan Susanto, 2009). Dinding sel mengandung asam alginik dan garam alginat. Kandungan koloid yang paling utama adalah algin yang diekstrak dari marga Sargassum, Turbinaria dan Macrocystis. Koloid algin dalam dunia perdagangan disebut asam alginik. Algin dalam bentuk derivat garam dinamakan garam alginat terdiri dari sodium alginat, potasium alginat dan amonium alginat. Garam alginat tidak larut dalam air, tetapi larut dalam larutan alkali. Kandungan koloid algin dalam industri kosmetik digunakan sebagai bahan pembuat sabun, fomade, cream, body lution, sampo dan cat rambut (Subaryono, 2010). Di bidang industri farmasi, digunakan sebagai bahan pembuat pembuat kapsul obat, tablet, salep, emulsifier, suspensi dan stabilizer (Kadi, 2004). Di bidang pertanian sebagai bahan campuran insektisida dan pelindung kayu, sedangkan di bidang industri makanan digunakan sebagai bahan saus, dan campuran mentega (Suparmi dan Sahril, 2009). Manfaat lainnya digunakan dalam industri fotografi, kertas, tekstil dan keramik. Di bidang kesehatan iodine yang terkandung di dalam rumput laut coklat dari kelompok "alginofit" dapat digunakan sebagai obat pencegah penyakit gondok (Kadi, 2004) 


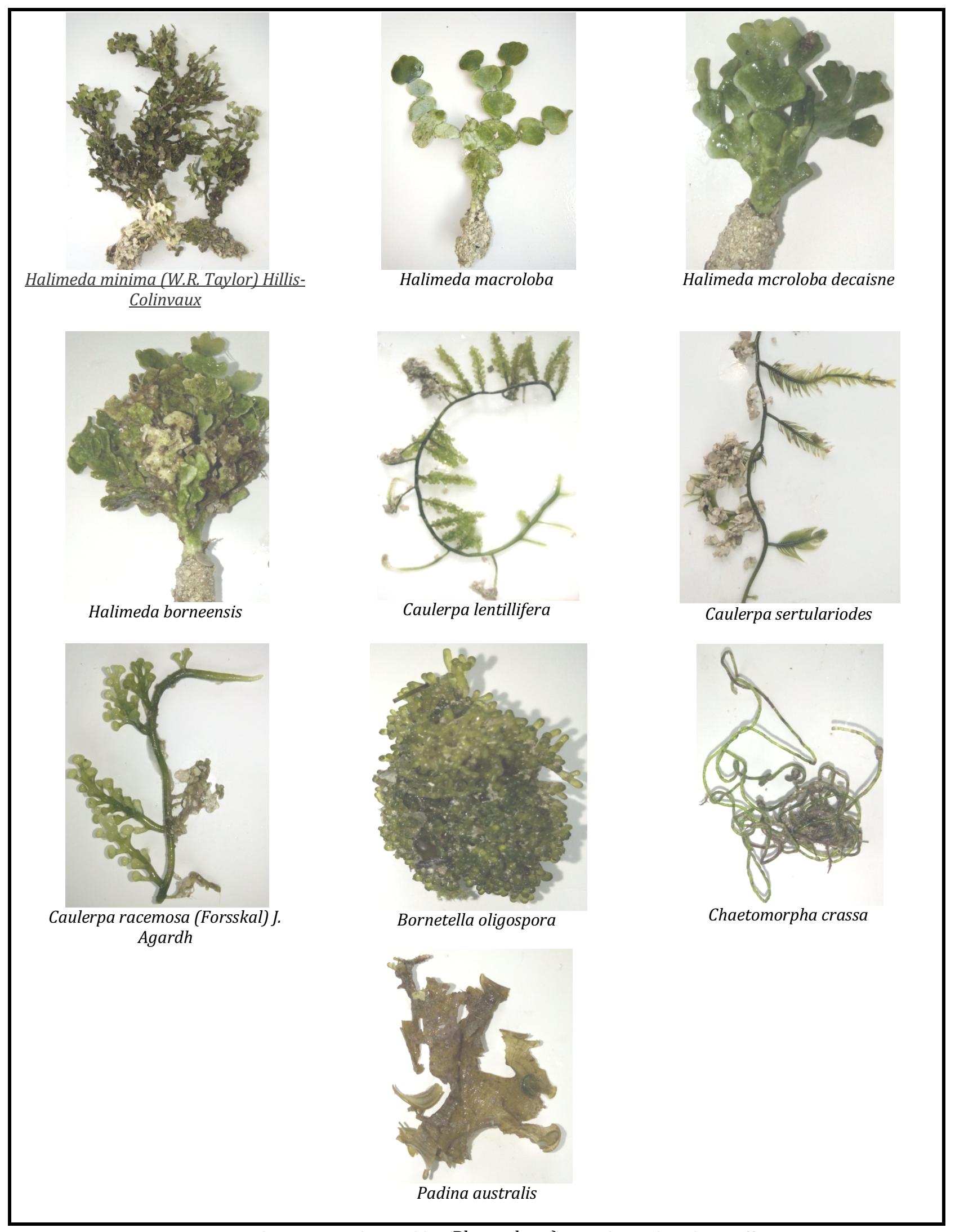

Gambar 8. Jenis Algae Coklat (Phaeophyta) yang ditemukan di P. Keffing 


\section{Algae Merah (Rhodophyta)}

Rumput laut merah ini di kenal sebagai penghasil karagenan dan agar. Karakteristik thalli mengandung figmen ficobilin dari ficoerithrin yang berwarna merah dan bersifat adaptasi kromatik (Kadi, 2004). Proforsi figmen dapat menimbulkan bermacam-macam warna thalli seperti warna coklat, violet, merah tua, merah muda, dan hijau. Dinding sel terdapat sellulose, agar, karagenan, profiran, dan furselaran. Persedian makanan dalam thalli berupa kanji (floridan starch) (Nybakken, 1992). Rumput laut merah mempunyai kandungan koloid utama adalah karagenan dan agar. Karagenan diekstrak dari marga Eucheuma, Gigartina, Rhodimenia dan Hypnea. Koloid agar diekstrak dari Gracilaria, Gelidium, Gelidiopsis dan Gelidiella. Di dunia perdagangan rumput laut merah ada dua kelompok yakni karagenofit dan agaroflt. Karagenan lebih dikenal sebagai asam karagenik. Koloid karagenan dalam bentuk derivat garam dinamakan karagenat terdiri dari potasium karagenat dan calcium karagenat (Kadi, 2004). Rumput laut merah penghasil agar sering disebut sebagai asam sulfirik atau asam agarinik. Bentuk derivat garam berupa kalcium agarinat, magnesium agarinat, potasium agarinat dan sodium agarinat (Setyorini dan Aanisa, 2017).

\section{1) Kelompok Agaroflt}

Adalah rumput laut merah penghasil koloid agar dan asam agarinik, diperoleh dari marga utama Gracilaria, Gelidium, Gelidiopsis dan Gelidiella. Di dunia industri kelompok ini dimanfaatkan sebagai bahan makanan (Kadi, 2004). Di bidang kedokteran "Agar"atau sering disebut "Agar Rose" jenis ini digunakan untuk media biakan bakteri. Di sektor pertanian digunakan sebagai media tumbuh jaringan tanaman (tissue-culture), sedangkan di bidang kesehatan sebagai obat anti desentri/diare dan anti gondok (Chilmi, 2020).

\section{2) Kelompok Karagenofit}

Adalah rumput laut merah penghasil koloid karagenan, asam karagenik dan garam karagenat. Koloid karagenan mempunyai fraksi iota dan kappa. Fraksi iota kandungan koloid karagenan larut dalam air dingin, dapat diperoleh dari jenis Eucheuma spinosum, Eucheuma isiforme dan Eucheuma uncinatum. Fraksi kappa kandungan koloid karagenan larut dalam air panas, dapat diperoleh dari jenis Eucheuma cottonii, Eucheuma edule dan Acanthophora (Kadi, 2004). Karagenan dari kelompok ini dimanfaatkan dalam industri makanan. Karaginan dapat dimanfaatkan seperti algin, sebagai bahan kosmetik, farmasi, pasta gigi dan salep. Khasiat lain dari marga Acanthophora dapat digunakan sebagai obat alami anti mikroba dan anti kesuburan

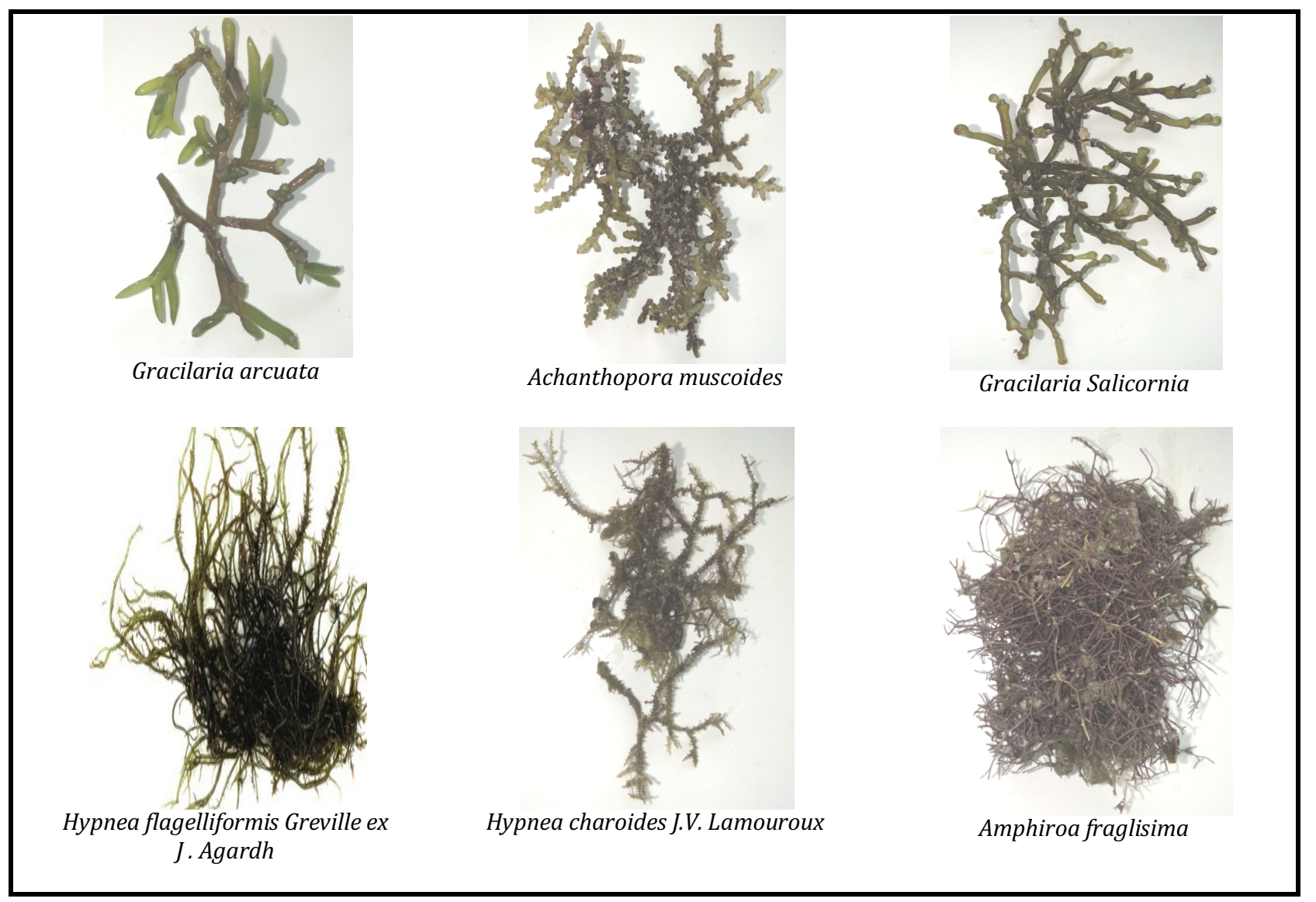

Gambar 8. Jenis Algae Merah (Rhodophyta) yang ditemukan di P. Keffing 
Tabel 6. Kegunaan Algae

\begin{tabular}{|c|c|c|}
\hline No & Nama & Kegunaan \\
\hline \multicolumn{3}{|c|}{ Chlorophyta } \\
\hline & Halimeda & $\begin{array}{l}\text { - Sumber karbonat di laut (perairan) (Nurhayati et al., 2017) } \\
\text { - } \text { Meningkatkan kesuburan periaran (Ain dan Widyorini, 2014) } \\
\text { - } \text { Obat anti Bakteri (Rau, 2018) } \\
\text { - Mengandung zat pertumbuhan auksin, gibberilin, dan Siktosin } \\
\text { (Kadi, 2014) }\end{array}$ \\
\hline 2 & Caulerpa & $\begin{array}{l}\text { - Makanan manusia (sayur /lalapan) (Ridhowati dan Asnani, 2016) } \\
\text { - Mengandung vitamin folik (Bistolen et al., 2021) } \\
\text { - Mengandung asam folat (Fatmawati et al., 2019) }\end{array}$ \\
\hline 3 & Ulva & $\begin{array}{l}\text { - Makanan manusia (Handayani, 2016) } \\
\text { - Mengandung vitamin E (Ulu et al., 2021) } \\
\text { - } \text { Obat anti bakteri (Handayani, 2016) }\end{array}$ \\
\hline \multicolumn{3}{|c|}{ Rhodophyta } \\
\hline 4 & Gracilaria & $\begin{array}{l}\text { - Makanan (sumber agar) (Waluyo et al., 2019) } \\
\text { - Mengandung protein dan lemak (Ate \& da Costa, 2017) } \\
\text { - } \text { Bidang bakteriologi (Panjaitan et al., 2020) } \\
\text { - } \text { Mengandung vitamin C dan iodine (Kadi, 2014) } \\
\text { - Obat disentri dan gondok (Kadi, 2014) }\end{array}$ \\
\hline 5. & Eucheuma & $\begin{array}{l}\text { - Sumber karaginan (Hermanto, 2021) } \\
\text { - Kontrol polusi metal Pb dan Cd (Wulandari dan Sukesi, 2013) }\end{array}$ \\
\hline 6 & Hypnea & $\begin{array}{l}\text { - Makanan manusia (Silaban, 2019) } \\
\text { - Sumber agar (Lalopua, 2017) }\end{array}$ \\
\hline \multicolumn{3}{|c|}{ Phaeophyta } \\
\hline 6 & Sargassum & $\begin{array}{l}\text { - Sumber alginat, tanin dan phenol (Pakidi dan Suwoyo, 2017) } \\
\text { - Makanan manusia (Chamidah et al., 2017) } \\
\text { - Mengandung protein, vitamin c dan iodine (Pakidi dan Suwoyo, } \\
\text { 2017) } \\
\text { - Obat gondok, anti bakteri dan anti tumor (Ghazali dan Hidayani, } \\
\text { 2021) }\end{array}$ \\
\hline 7 & Padina & $\begin{array}{l}\text { - Makanan manusia (Kalalo et al., 2014) } \\
\text { - Sumber alginate (Pasaribu et al. 2020) }\end{array}$ \\
\hline
\end{tabular}

\subsection{Faktor Lingkungan}

Dari penjelasan sebelumnya, maka beberapa kegunaan makroalgae yang dapat dilihat pada Tabel 6 . Makroalgae yang dimaksud adalah Halimeda, Caulerpa, Ulva, Glacilaria, Eucheuma, Hypnea, Sargasum, dan Padina.

Faktor lingkungan yang mempengaruhi pertumbuhan makroalgae tidak hanya tipe substrat, melainkan faktor-faktor lingkuan lainnya, seperti suhu, pH, kedalaman air, dan kuat arus air. Hasil pengukuran parameter lingkungan di lokasi penelitian menunjukkan bahwa kondisi lingkungan di perairan Pulau Keffing sesuai untuk pertumbuhan makrolaga. Suhu di lokasi penelitian berkisar $28,5-29,5^{\circ} \mathrm{C}$. Suhu tersebut masih termasuk suhu optimum untuk pertumbuhan makroalgae yang berkisar $25-31{ }^{\circ} \mathrm{C}$. Begitupula dengan $\mathrm{pH}$, kuat arus dan kedalaman air di perairan Pulau Keffing masing-masing 7-8 untuk pH, 5 - $70 \mathrm{~cm} / \mathrm{s}$ untuk kuat arus, serta $0-36,8 \mathrm{~m}$ untuk kedalaman air yang masih dapat ditembus cahaya. Pertumbuhan makroalgae dapat berlangsung terusmenerus pada kisaran $\mathrm{pH}$ 7-8, kuat arus ideal untuk pertumbuhan makroalgae adalah 20-40, dan kedalaman air 30-90 cm makroalgae masih dapat hidup, karena sinar matahari masih dapat menembus sampai dasar perairan sehingga makroalgae dapat melakukan fotosintesis (Diansyah et al., 2018).

\subsection{Rekomendasi Pengelolaan}

Berdasarkan hasil penelitian yang dilakukan di Pulau Keffing Kecamatan Seram timur, Kabupaten Seram Bagian Timur, maka beberapa Rekomendasi kepada Pemerintah kabupaten Seram Bagian Timur dan Pemangku Kepentingan adalah bahwa Kepulauan Seram Bagian Timur khususnya Pulau Keffing memiliki potensi untuk dilakukan kegiatan budidaya rumput laut serta usaha pengolahan produknya seperti rumput laut (Eucheuma Spp., Sargassum Spp., Turbinaria Spp., Gracilaria Spp.).

\section{Kesimpulan}

Berdasarkan hasil penelitian yang dilakukan di perairan Pulau Keffing Kecamatan Seram timur, Kabupaten Seram Bagian Timur, maka dapat disimpulkan potensi sumber daya algae di pulau Keffing cukup baik. Jumlah jenis algae yang dijumpai dalam penelitian ini sebanyak 16 jenis yang terdiri atas 9 jenis dari kelas algae Chlorophyta, 1 jenis dari kelas Phaeophyta dan 6 jenis dari kelas Rhodophyta. Jenisjenis yang ditemukan memiliki potensi ekonomi, baik 
kepada lingkungan perairan maupun kepada manusia, namun pemanfaatannya belum dioptimalkan oleh masyarakat karena sebagian hanya dimanfaatkan untuk makanan. Dari hasil pengukuran parameter lingkungan sesuai bagi pertumbuhan makroalgae. Perairan pulau Keffing dan sekitarnya memiliki kemungkinan untuk dikembangkannya kegiatan usaha budidaya rumput laut serta pengembangan pengolahan potensinya.

\section{DAFTAR PUSTAKA}

Ain, N., \& Widyorini, N. (2014). Hubungan kerapatan rumput laut dengan substrat dasar berbeda di Perairan Pantai Bandengan, Jepara. Management of Aquatic Resources Journal (MAQUARES), 3(1), 99-107.

Ameilda, Cut H., I. Dewiyanti, C. Octavina. 2016. Struktur Komunitas Perifiton pada Makroalga Ulva Lactuca di Perairan Pantai Ulee Lheue, Banda Aceh. Jurnal Ilmiah Mahasiswa Kelautan Perikanan Unsyiah, vol. 1, no. 3.

Ate, J. N. B., \& da Costa, J. F. 2017. Analisis kandungan nutrisi Gracilaria edule (SG Gmelin) PC Silva dan Gracilaria coronopifolia J. Agardh untuk pengembangan perekonomian masyarakat pesisir. Jurnal Ilmu Kesehatan, 5(2), 94-103.

Atmadja, W. S. 2009. Pengenalan Jenis-Jenis Rumput Laut Indonesia, Publistbang Oseonologi LIPI. Jakarta

Bandeira-Pedrosa, M.E., S.M.B. Pereira, and E.C. Oliveira. 2004. Taxonomy and distribution of the green algal genus Halimeda (Bryopsidales, Chlorophyta) in Brazil. Revista Brasil. Bot., V.27, n.2, p.363-377, abr.jun. 2004

Bhavanath, J., C.R.K. Reddy, and C.T. Mukund. 2009. Seaweed of India. The diversity and distribution of seaweed of the Gujarat Coast. 232p.

Bistolen, O., A. Tjendanawangi, Y. Salosso. 2021. Pengaruh jarak tanam yang berbeda terhadap pertumbuhan rumput laut Caulerpa racemossa. Jurnal Aquatik. Volume 4 Nomor 1.

Chamidah, A., Marsono, Y., Harmayani, E., \& Haryadi, H. 2013. Pengaruh Metode Ekstraksi terhadap Karakteristik Crude Laminaran dari Sargassum duplicatum. agriTECH, 33(3), 251-257.

Chilmi, L. 2020. Optimasi Random Amplified Polymorphic DNA (RAPD) pada karakterisasi molekular Maja (Aegle marmelos (L.) Corr.) di Kabupaten dan Kota Mojokerto. Doctoral dissertation, UIN Sunan Ampel Surabaya.

Codero, P.A.J. 1980. Taxonomy and distribution of Philiphine useful seaweed. National Research Council of the Philipines. Bictun, Tagig, Metro Manila Philipines. 73p

Dahuri, R, Rais, P. Ginting, M.J. Sitepu. 1996. Pengelolaan Sumberdaya Pesisir dan Laut Secara Terpadu. P.T Pradnya Paramita. Jakarta.

Dawes, C. J. 1981. Marine Botany. John Wiley and Sons University of South Florida. New York.

Diansyah, S., Kusumawati, I., \& Hardinata, F. (2018). Inventarisasi Jenis-Jenis Makroalga Di Pantai Lhok Bubon Kecamatan Samatiga Kabupaten Aceh Barat. Jurnal Perikanan Tropis, 5(1), 93-103.

Draw, E.A. 1995. Diversity of the green algal genus Halimeda in the Chagos Archipelago, central Indian Ocean. Aquatic Botany. Volume 52, Issues 1-2, ISSN 0304-
3770 , 3770(95)00482-F

https://doi.org/10.1016/0304-

Dubinsky, Z., T. Berner, and Saaronson. 1978. Potential of large algae culture for biomss and lipid production in Prid Lands. In: Biotechnology in energy production and conservation. (C. D. Scott ed.). Biotechnology and Bioengenering Symp. S. John wille \& Sons :51-68.

Dzeha, T., Jaspars, M., \& Tabudravu, J. 2003. Clionasterol, a triterpenoid from the Kenyan marine green macroalga Halimeda macroloba. Western Indian Ocean Journal of Marine Science, 2(2), 157-161.

Fatmawati, R.K., A. C. Aditya, dan M. Susanti. 2019. Teknik Budidaya Rumput Laut (Caulerpa racemosa) Dengan Metode Sebar Di Balai Besar Perikanan Budidaya Air Payau Jepara, Jawa Tengah. Prosiding Seminar Nasional MIPA 2019 Universitas Tidar.

Fifendy, M. 2017. Mikrobiology. 226 hlmn. Kencana: Depok.

Firdaus, M. 2019. Pigmen Rumput Laut dan Manfaat Kesehatannya. 134 hal. UB Press Malang

Ghazali, M., Zaki, M., \& Hidayati, E. 2021. Antibacterial Activity of Methanol Extract of Sargassum polycystum on Escherichia coli and Staphylococcus aureus. Jurnal Biologi Tropis, 21(1), 199-205.

Handayani, T. 2016. Karakteristik Dan Aspek Biologi Ulva spp. (Chlorophyta, Ulvaceae). J. Oseana, 41(1), 1-8.

Hermanto, K. P. 2021. Pengaruh Perbedaan Konsentrasi Larutan Alkali $\mathrm{Ca}(\mathrm{OH})_{2}$ Terhadap Mutu Tepung Karagenan Yang Dihasilkan Euchema cottonii. Jurnal Akuatek Vol, 2(1), 51-57.

Irawan, S. dan O.M. Luthfy. 2017. Identifikasi Jenis Makroalga Pada Mikro Atoll Karang Porites di Pantai Kondang Merak, Kabupaten Malang. Journal Ilmiah Rinjani_Universitas Gunung Rinjani Vol. 5 No. 1

Kadi, A. 2004. Rumput laut di beberapa perairan pantai Indonesia. J. Oseanologi di Indonesia, 4:25- 36.

Kadi, A. 2005. Beberapa Catatan Kehadiran Marga Sargassum di Perairan Indonesia. Oseana, Volume XXX, Nomor 4, 2005: 19 - 29

Kadi, A. 2014. Rumput Laut Sebagai Produk Alam dari Perairan Indonesia. Oseana. Volume XXXIX, Nomor 3;31-40

Kalalo, J. L., Mantiri, D., \& Rimper, J. 2014. Analisis jenis-jenis pigmen alga coklat Padina australis Hauck dari perairan laut Sulawesi.Jurnal Pesisir dan Laut Tropis, 2(1), 8-12.

Lalopua, V. M. 2017. Pemanfaatan dan karakteristik nori tiruan menggunakan bahan baku alga Hypnea saidana dan Ulva conglubata dari perairan Maluku. Majalah Biam, 13(02), 33-40.

Linares, A.F., Loikkanen J., Jorge M.F., Soria RB, Novoa A.V., 2004. Antioxidant and neuroprotective activity of the extract from the seaweed, Halimeda incrassata (Ellis) Lamouroux, against in vitro and in vivo toxicity induced by methyl-mercury. Vet Hum Toxicol 46: 1-5.

Luning., 1990. Seaweeds, Their Environment Biogeography and Ecophysiology. John Wiley and Sons. New York.

Mtolera, M.S.P. \& A. Semesi. 1996. Antimicrobial Activity of Extracts from Six Green Algae from Tanzania. Current Trends in Marine Botanical Research in East African Region. p.211- 217

Merdekawati, W. dan A.B. Susanto. 2009. Kandungan Dan Komposisi Pigmen Rumput Laut Serta Potensinya Untuk Kesehatan. Squalen Vol. 4 No. 2

Nurhayati, N., Apriani, S. N. K., Nurbayasari, R., \& Murdinah, M. 2017. Komposisi Nutrisi Rumput Laut Calcareous 
Halimeda opuntia pada Lingkungan Perairan Indonesia.Jurnal Pascapanen dan Bioteknologi Kelautan dan Perikanan, 12(1), 13-22.

Nybakken, J. W. 1992. Biologi laut. Suatu Pendekatan Ekologis. PT Gramedia. Jakarta, 325-363.

Odum, E.P. 1993. Dasar-dasar Ekologi. Terjemahan Tjahjono Samingan. Edisi Ketiga. Yogyakarta: Gadjah Mada University Press.

Pakidi, C. S., \& Suwoyo, H. S. (2017). Potensi dan pemanfaatan bahan aktif alga cokelat Sargassum sp. Jurnal Octopus, 6(1), 551-562.

Panjaitan, R. S., Simanjuntak, Y. V., \& Sumantri, S. 2020. Ekstrak Lemak Gracilaria verrucosa sebagai Antibakteri Shigella dysentriae dan Escherichia coli. Jurnal Pascapanen dan Bioteknologi Kelautan dan Perikanan, 15(1), 13-20.

Papalia, S. dan Arfah, H. 2013. Produktivitas biomasa makroalga di perairan pulau ambalau, kabupaten buru selatan. Jurnal Ilmu dan Teknologi Kelautan Tropis, Vol. 5, No. 2, Hlm. 465-477.

https://doi.org/10.29244/jitkt.v5i2.7574

Pasaribu, A. S., Sedjati, S., \& Pramesti, R. (2020). Analisis Kualitas Alginat Rumput Laut (Padina sp.) Menggunakan Metode Ekstraksi Jalur Kalsium. Journal of Marine Research, 9(1), 75-80.

Rau, C. H. 2018. Isolasi, identifikasi secara molekuler menggunakan gen 16s rrna, dan uji aktivitas antibakteri bakteri simbion endofit yang diisolasi dari alga Halimeda opuntia. PHARMACON, 7(2).

Ridhowati, S. dan Asnani. 2016. Potensi Anggur Laut Kelompok Caulerpa racemosa Sebagai Kandidat Sumber Pangan Fungsional Indonesia. Oseana. Volume XLI, Nomor 4, 2016:50-62.

Setyorini, D. \& Aanisah, R. 2017. Ekstraksi Senyawa Fitokimia dari Alga Eucheuma cottonii dan Gracilaria sp menggunakan $\mathrm{CO} 2$ Superkritis dan Air Subkritis sebagai Pelarut. Doctoral dissertation, Institut Teknologi Sepuluh Nopember.

Silaban, R. 2019. Komunitas Makro Alga Di Perairan Pantai Desa Wakal, Kabupaten Maluku Tengah.Jurnal Sumberdaya Akuatik Indopasifik, 3(1).

Smith, D. G. and G. E. Yonge. 1955. The Combined amino acid in several species of Marine algae. J. Biol Chem.: 645 853.
Subaryanti, I.M. Artama, I. Kadir. 2013. The Influence of Gamma Irradiation into The Dry Red Algae Quality from Nusa Dua Bali. SAINSTECH. Vol. 23 No. 2. https://doi.org/10.37277/stch.v23i2.602

Subaryono. 2010. Modifikasi Alginat Dan Pemanfaatan Produknya. SQUALEN Vol. 5 No. 1.

Suparmi dan Sahri. A., 2009. Mengenal Potensi Rumput Laut: Kajian Pemanfaatan Sumber Daya Rumput Laut Dari Aspek Industri Dan Kesehatan. Sultan Agung Vol XLIV No. 118

Ulu, H. N., Jelantik, I. G. N., Sutedjo, H., \& Sudarma, I. M. 2021. Rumput Laut (Ulva lactuca) sebagai Pakan Substitusi Sapi Bali Sapihan di Musim Kemarau dengan Level Energi yang Berbeda.Jurnal Sain Peternakan Indonesia, 16(1), 17-25.

Waluyo, W., Permadi, A., Fanni, N. A., \& Soedrijanto, A. 2019. Analisis kualitas rumput laut Gracilaria verrucosa di tambak Kabupaten Karawang, Jawa Barat. Grouper: Jurnal Ilmiah Fakultas Perikanan Universitas Islam Lamongan, 10(1), 32-41.

Windyaswari, A. S., Elfahmi, E., Faramayuda, F., Riyanti, S., Luthfi, O. M., Ayu, I. P. \& Magfirah, R. 2019. Profil fitokimia selada laut (Ulva lactuca) dan mikro alga filamen (Spirogyra sp) sebagai bahan alam bahari potensial dari perairan Indonesia. Kartika: Jurnal Ilmiah Farmasi, 7(2), 88-101.

Wulandari, E. A., \& Sukesi, S. 2013. Preparasi Penentuan Kadar Logam $\mathrm{Pb}, \mathrm{Cd}$ dan $\mathrm{Cu}$ dalam Nugget Ayam Rumput Laut Merah (Eucheuma cottonii). Jurnal Sains dan Seni ITS, 2(2), C15-C17.

Yoshie, Y., W. Wang, Y. P. Hsieh, \& T. Suzuki. 2002. Compositional Difference of Phenolic Compounds between Two Seaweeds, Halimeda spp. J. of Tokyo Univ. of Fisheries 88: 21-24

Yoshie, O., Fujisawa, R., Nakayama, T., Harasawa, H., Tago, H., Izawa, D., \& Yamada, Y. (2002). Frequent expression of CCR4 in adult T-cell leukemia and human T-cell leukemia virus type 1 -transformed T cells. Blood, The Journal of the American Society of Hematology, 99(5), 1505-1511 